\title{
Production of a bi-specific monoclonal antibody recognizing mouse kappa light chains and horseradish peroxidase
}

\section{Applications in immunoassays}

\author{
R.L. Kenigsberg and A.C. Cuello \\ Department of Pharmacology and Therapeutics, McGill University, 3655 Drummond Street, Montreal, Quebec, Canada H3G 1 Y6
}

Accepted September 17, 1990

Summary. The production of a bi-specific monoclonal antibody that simultaneously recognizes mouse kappa light chains and horseradish peroxidase (HRP) for use as a general developing reagent in a wide variety of immunobased techniques is described. This antibody, named $\mathrm{McC} 10$, was produced by the fusion of an aminopterin-sensitive interspecies hybridoma which secretes rat monoclonal antibodies against $\mathrm{HRP}\left(\mathrm{RAP}_{2} \cdot \mathrm{Ag}\right)$ and splenocytes from a rat immunized with whole mouse immunoglobulin (Ig)G. The hybrid-hybridoma generated from this fusion expresses and secretes rat Igs of the $\mathrm{IgG}_{1}$ and $\mathrm{IgG}_{2 \mathrm{a}}$ subclasses, as determined by radial immunodiffusion. In competitive binding solid-phase enzymatic assays, $\mathrm{McCl} 10$ was found to cross-react with all four mouse IgG subclasses as well as mouse kappa light chains. In contrast, in this type of assay, McC10 did not appear to recognize mouse IgA, IgM or lambda light chains. However, IgM-bearing kappa light chains were recognized by immunocytochemistry. Epitope specificity of this bi-specific antibody was more clearly determined on immunoblots where McC10 was found to exclusively recognize mouse kappa light chains and display no cross-reactivity with mouse Ig heavy chains nor with kappa light chains from rat or rabbit. In addition, McC10 was used successfully in two-step immunocytochemistry (ICC) for the localization of enkephalin, nerve growth factor (NGF) receptor and paired helical filament-immunoreactive sites in rat brain, rat skin and human brain, respectively, using mouse IgG's and IgM's as primary antibodies. McC10 compared favourably with peroxidase-anti-peroxidase (PAP) ICC with respect to sensitivity but was markedly superior with respect to specificity when used in fixed human brain or rat skin. This study demonstrates some of the potential advantages of using an epitope specific monoclonal bi-specific developing reagent like $\mathrm{McC} 10$ in an immunobased technique like ICC. Its potential use in a variety of other immunobased procedures is discussed.

\section{Introduction}

Hybridoma technology has made a considerable impact in immunocytochemistry (ICC) and a variety of other immunobased techniques. This technology has provided an unlimited supply of standard, well characterized and highly specific antibodies from pure or impure immunogens. Consequently, it is not surprising that monoclonal antibodies are increasingly used as primary antibodies in a large number of studies. When using primary monoclonal antibodies, immunostaining can be obtained with the use of direct, indirect or unlabelled staining procedures (Sternberger et al. 1970). Techniques which depend upon external chemical conjugation protocols may suffer from a number of shortcomings like loss of immunoreactivity. Thus, they have been favoured by the unlabelled immunobased staining procedure. Hybridoma technology has also contributed to developments in this latter technique with the production of monoclonal antiimmunoglobulin (Ig) (MacMillan et al. 1984) and antiperoxidase (Cuello et al. 1984b; Mason et al. 1982; Semenenko et al. 1985) antibodies. More recently, with the development of two new techniques [internal radiolabelling of monoclonal antibodies (Cuello and Milstein 1981; Cuello et al. 1982) and the production of bi-specific monoclonal antibodies (Milstein and Cuello 1983; 1984)], hybridoma technology has renewed interest in direct immunostaining procedures. Bi-specific monoclonal antibodies which possess binding sites for the antigen under investigation and an immunohistochemical marker like horseradish peroxidase (HRP) on the same Ig molecule have been produced and used successfully in a variety of studies (Suresh et al. 1986; Semenenko et al. 1988; Kenigsberg et al. 1990). Bi-specific monoclonal antibodies used in one- or two-step immunocytochemistry (ICC) have been found to be remarkably sensitive and highly specific, dramatically enhancing the signal-to-noise ratio. Furthermore, the introduction of these bi-specific monoclonal antibodies has considerably shortened standard staining procedures. These shortened protocols may inevitably help to preserve tissue 
and antigen integrity which is especially important for ultrastructural studies at the electron microscopic level. Despite these observations, it will undoubtedly become an overwhelming task to develop bi-specific monoclonal antibodies for every antigen under investigation. Consequently, we have attempted to overcome this step and further the use of the bi-specific antibodies by producing a bi-specific developing antibody capable of the simultaneous recognition of mouse Igs and HRP to be used as general developing reagents. The generation of this bi-specific antibody, its characterization and its use in two-step immunostaining procedures are described.

\section{Materials and methods}

\section{Immunizations}

Adult female Sprague Dawley (Charles River) rats were immunized with 500,50 or $5 \mu \mathrm{g} /$ injection of either HRP (Sigma Grade VI) or whole mouse IgG (Schripps). Both immunogens were first dissolved in phosphate buffered saline (PBS) pH 7.4 and then emulsified in an equal volume of Freund's adjuvant (Difco). Each rat received a total of $200 \mu \mathrm{l}$ of the emulsified immunogen per injection which was administered in multiple sites intracutaneously and intraperitoneally (Vaitukaitis et al. 1971). The animals received a total of four such injections, the first three administered at weekly intervals and the final after a 3 -week rest period. Five to 10 days after the final immunization, blood samples were obtained and the presence of anti-HRP antibodies was determined in conventional peroxidase antiperoxidase (PAP) ICC. The presence of antimouse IgG antibodies in animal sera was assessed in conventional PAP ICC and the direct enzyme-linked immunosorbent assay (ELISA), using whole mouse IgG as the coating antigen. Three to 4 days before fusion, the appropriate host animal received an intrasplenic boost (Spitz et al. 1984) of either immunogen dissolved in PBS at the dose used in the previous immunizations

\section{Cell fusion}

Both fusions were carried out as described previously (Kohler and Milstein 1975; Kohler et al. 1976) with several modifications. Splenocytes from a hyperimmune rat immunized with HRP were mixed with non-producing mouse myeloma cells $\mathrm{Sp}_{2} / \mathrm{O} \cdot \mathrm{Ag}$ at a ratio of $10: 1$, respectively. The mixed cells were pelleted by centrifugation at $100 \mathrm{~g}$ for $5 \mathrm{~min}$ and then exposed to the fusagen, $45 \%$ polyethylene glycol (PEG) (BDH) and 5\% dimethyl sulfoxide for a total of $2 \mathrm{~min}$. Dimethyl sulfoxide was included since it has been found to significantly enhance PEG-induced fusion (Norwood et al. 1976). Five millilitres of glucose potassium (GKN) buffer, containing $8.0 \mathrm{~g} \mathrm{NaCl}, 0.4 \mathrm{~g} \mathrm{KCl}, 3.56 \mathrm{~g} \mathrm{Na}_{2} \mathrm{PO}_{4}, 0.78 \mathrm{~g} \mathrm{NaH}_{2} \mathrm{PO}_{4}$, $5.0 \mathrm{~g}$ glucose and $0.01 \mathrm{~g}$ phenol red/1 $\mathrm{H}_{2} \mathrm{O}$ (MRC Cellular Immunology Unit, Oxford, UK), was than added over 1 min and the volume was increased to $45 \mathrm{ml}$ with GKN buffer. The cells were then collected by centrifugation at $100 \mathrm{~g}$, resuspended to a final volume of $48 \mathrm{ml}$ in RPMI 1640 (Gibco) supplemented with $20 \%$ fetal bovine serum (FBS) (Gibco) and then equally distributed in 4 24-multiwell Corning plates (Fisher Scientific), already containing a feeder layer of $1 \times 10^{6}$ rat spleen cells per well. The following day, $1 \mathrm{ml}$ of RPMI, $20 \%$ FBS plus double strength hypoxanthine aminopterin thymidine (Sigma) was added to each well. Hybrid cell growth was monitored and media was replenished when necessary. Ten to 30 days after fusion, spent media was collected from wells with conspicuous hybrid cell growth and tested for presence of antiperoxidase antibodies by PAP ICC. Positive hybrids were cloned twice by limiting dilution, expanded and then frozen in liquid $\mathrm{N}_{2}$. One final hybridoma, secreting monoclonal antibodies against HRP coded $\mathrm{RAP}_{2}$, was rendered resistant to 8-azaguanine (ICN) in a step-wise manner by growing the hybridoma in successively higher doses of 8-azaguanine. Cells surviving in $15 \mu \mathrm{g} / \mathrm{ml}$ 8-azaguanine were then cloned by limiting dilution and retested for antiperoxidase activity as well as aminopterin sensitivity. The final aminopterin-sensitive anti-HRP hybridoma was coded $\mathrm{RAP}_{2}$. $\mathrm{Ag}$.

For the production of the hybrid-hybridoma, splenocytes from a rat immunized with whole mouse IgG were once again mixed with $\mathrm{RAP}_{2} \cdot \mathrm{Ag}$ cells at a ratio of $10: 1$, respectively. Fusion was carried out essentially as described for the production of rat antiperoxidase antibodies. The presence of bi-specific anti-mouse IgG antiperoxidase activity in fusion wells and subsequent clones was determined by the direct ELISA, using whole mouse IgG as the coating antigen. Positive supernatants were retested by direct ELISA with the 4 heavy chain subclasses of mouse IgG and in ICC with appropriate mouse primary antibodies. One clone, named $\mathrm{McC10}$, was eventually isolated and used for final characterization.

\section{Direct ELISA}

Incubations were carried out at room temperature and the volume of reagents added per well for all steps except blocking were kept constant at $50 \mu \mathrm{l}$. In addition, assay wells were washed 3 to 4 times with PBS, following each of the incubation steps. Microassay (Immunlon I, Dynatech) plates were coated with either $50 \mu \mathrm{g} / \mathrm{ml}$ whole mouse IgG (Schripps), $10 \mu \mathrm{g} / \mathrm{ml}$ purified mouse IgG subclasses (ICN) or PBS alone (control wells) for $2 \mathrm{~h}$. Unoccupied binding sites were subsequently blocked by incubating for $1 \mathrm{~h}$ with $200 \mu \mathrm{l} /$ well of a $1 \%$ ovalbumin solution (Sigma) prepared in PBS. Following this step, mouse anti-HRP monoclonal antibodies (MAP.A6, Semenenko et al. 1985) were preincubated with $5 \mu \mathrm{g}$ $\mathrm{HRP} / \mathrm{ml}$ for $1 \mathrm{~h}$ at room temperature and then applied to the microassay wells for a $45 \mathrm{~min}$ incubation. Finally, peroxidase activity was determined colourimetrically with $0.4 \% 2,2$-azino-bis (3-ethylbenzthiazoline sulfonic acid) (ABTS, Sigma) and $0.01 \% \mathrm{H}_{2} \mathrm{O}_{2}$ prepared in phosphate citrate buffer $\mathrm{pH} 4.0$. The peroxidase reaction was allowed to proceed over a $30-\mathrm{min}$ period and was then stopped with the addition of $1 \%$ oxalic acid. The change in optical density was determined at $414 \mathrm{~nm}$ with the use of an EIA-Reader (Bio-Rad Model 2550).

For the determination of bi-specific antibody activity, the microassay plates were coated and blocked as described above. Following the blocking step, hybrid-hybridoma supernatant from fusion wells or clones were preincubated with HRP $(5 \mu \mathrm{g} / \mathrm{ml}$ supernatant) for $1 \mathrm{~h}$ before application to the assay wells. Incubation with culture supernatant was allowed to proceed over a 1 -h period and peroxidase activity was revealed as previously described.

\section{Dilution curve for $\mathrm{McC} 10$}

Optimal coating efficiency for whole mouse IgG was determined by the peroxidase saturation technique and by the checker-board titration technique (Munoz et al. 1986), using undiluted McC10 supernatant supplemented with HRP $(5 \mu \mathrm{g} / \mathrm{ml})$. The optimum solid-phase antigen coating concentration determined by the two different methods were very similar and were found to be approximately $2 \mu \mathrm{g}$ mouse IgG/ml PBS. Consequently, this coating concentration was used in all subsequent assays.

Microassay wells were coated with $2 \mu \mathrm{g} / \mathrm{ml}$ whole mouse $\mathrm{IgG}$ and blocked as previously described. McC10 hybridoma supernatant was serially diluted in PBS and supplemented with HRP (final concentration, $5 \mu \mathrm{g} \mathrm{HRP} / \mathrm{ml}$ ). Peroxidase activity was determined as detailed earlier and a dilution curve for $\mathrm{McCl} 10$ was constructed. The dilution of the hybridoma supernatant, which fell on the linear portion of the curve, was used in the competitive binding assays. 


\section{Competitive binding assay}

Competitive binding assays, with purified mouse IgG subclasses, IgA, IgM, lambda and kappa light chains, were performed using McC10 supernatant diluted $1: 150$ in PBS and preincubated with various amounts of the mouse immunoglobulins. The final concentration of HRP added to these supernatants was kept constant at $5 \mu \mathrm{g} / \mathrm{ml}$. Mouse $\operatorname{IgG}_{1}, \operatorname{IgG}_{2 \mathrm{a}}, \operatorname{IgG}_{2 \mathrm{~b}}$ and $\operatorname{IgG}_{3}$ are myeloma IgGs isolated from the tumour lines MOPC $21\left(\mathrm{IgG}_{1 \mathrm{k}}\right)$, UPC 10 and RPC $5\left(\operatorname{IgG}_{2 \mathrm{ak}}\right)$ or J606 and FLOPC $21\left(\mathrm{IgG}_{3 \mathrm{k}}\right)$, respectively. Mouse $\operatorname{IgA}$ and IgM are myeloma Igs isolated from the tumour lines MOPC $315\left(\operatorname{IgA}_{\lambda 2}\right)$ or TEPC $\left(\operatorname{IgM}_{k}\right)$, respectively, while mouse kappa and lambda light chains were isolated from MOPC 41 or RPC 20 tumour lines. All mouse tumours were of $\mathrm{BALB} / \mathrm{c}$ origin. Microassay wells were coated with $2 \mu \mathrm{g} / \mathrm{ml}$ whole mouse IgG and blocked as previously described. Incubations with diluted McC10 supernatants with or without competing immunoglobulins, were allowed to proceed over $1 \mathrm{~h}$. Peroxidase activity was assessed as described above.

\section{Radial immunodiffusion}

To determine the classes and subclasses of the rat antiperoxidase $\left(\mathrm{RAP}_{2}\right)$ and bi-specific $(\mathrm{McC} 10)$ monoclonal antibodies, hybridoma supernantants were concentrated 10 -fold with a Minicon concentrator (Amicon Corp.). Seventy-five microlitres of the concentrated supernatants were added to the central wells of a $1 \%$ agarose gel, and $10 \mu \mathrm{l}$ of highly specific rabbit antisera against each of the 4 heavy chain subtypes of mouse $\operatorname{IgG}$ as well as $\operatorname{IgA}$ and $\operatorname{IgM}$ (Serotec) were applied to the surrounding wells. The development of sharp precipitin lines could be visualized within 2 days.

\section{Polyacrylamide gel electrophoresis, Western blots and immunoblots}

Whole mouse, rat and rabbit $\operatorname{IgG}$, as well as mouse $\operatorname{IgA}, \operatorname{IgM}$, the four heavy chain subclasses of mouse IgG, mouse and rat kappa light chains and mouse lambda light chains, were electrophoretically separated on $10 \%$ polyacrylamide slab gels under denaturing conditions using $\beta$-mercaptoethanol as a reducing agent. In addition, IgM was also separated after reduction with dithiothreitol. After separation, the proteins were transferred electrophoretically onto nitrocellulose membranes at $20 \mathrm{~V}$ for $8 \mathrm{~h}$ with the use of a trans-blot apparatus (Bio-Rad). A portion of the membrane containing the molecular weight standards was cut, and the bands were revealed with $1 \%$ Amido black. The remaining part of the membrane was blocked with $5 \%$ bovine serum albumin for $1 \mathrm{~h}$ at $37^{\circ} \mathrm{C}$ and then incubated for $1 \mathrm{~h}$ at room temperature with undiluted $\mathrm{McC} 10$ hybridoma supernatant which had been preincubated with HRP $(5 \mu \mathrm{g} / \mathrm{ml})$. The blots were then washed 3 to 4 times with PBS and finally exposed to the peroxidase substrates, $0.06 \%$ diaminobenzidine (DAB, Sigma) and $0.01 \% \mathrm{H}_{2} \mathrm{O}_{2}$ in PBS. The peroxidase reaction was stopped after $10-15 \mathrm{~s}$ by removal of the substrates, washed extensively with PBS and then dried and photographed.

\section{Detection of antiperoxidase activity for the production of a rat anti-HRP monoclonal antibody}

The following immunocytochemical procedure was used for the detection of antiperoxidase activity. Forty $\mu \mathrm{m}$ sledge microtome sections of $4 \%$ paraformaldehyde fixed rat spinal cord were incubated overnight at $4^{\circ} \mathrm{C}$ with $1: 100(\mathrm{v} / \mathrm{v})$ anti-substance $\mathrm{P}$ rat monoclonal antibody (NCl/34, Cuello et al. 1979), diluted in PBS/0.2\% Triton X-100 (PBS $+\mathrm{T})$. Sections were then washed in $\mathrm{PBS}+\mathrm{T}$ and incubated for $1 \mathrm{~h}$ at room temperature with dialyzed fractionated rabbit antisera containing anti-rat IgG antibodies (Sigma). This antisera was reconstituted according to directions and then further diluted 1:20 in PBS $+\mathrm{T}$ before use. Following this, sections were incubated for $1 \mathrm{~h}$ at room temperature in diluted sera collected from rats which had been immunized with HRP or with undiluted supernatant from fusion wells or clones in the generation of $\mathrm{RAP}_{2}$. The diluted rat sera or hybridoma supernatants were preincubated with HRP $(5 \mu \mathrm{g} / \mathrm{ml})$ for at least $1 \mathrm{~h}$ at room temperature before being applied to the tissue sections. After washing with $\mathrm{PBS}+\mathrm{T}$, sections were exposed to $0.06 \% \mathrm{DAB}$ for $15 \mathrm{~min}$ and then $\mathrm{H}_{2} \mathrm{O}_{2}$ (final concentration $0.01 \%$ ) was added. Sections were then washed free of substrates, dehydrated, cleared and mounted for visualization. All microtome sections were processed free-floating.

\section{Immunocytochemical localization of NGF receptor, enkephalin and paired helical filament immunoreactivity}

Adult male Wistar rats were perfused transcardially with a mixture of $4 \%$ paraformaldehyde, $0.1 \%$ glutaraldehyde and $15 \%$ saturated picric acid solution in $0.1 \mathrm{M}$ phosphate buffer, $\mathrm{pH} 7.4$, followed by the same fixative mixture devoid of glutaraldehyde. After perfusion, the lower lips were excised and further fixed by immersion in the latter fixative mixture for $1 \mathrm{~h}$ at $4^{\circ} \mathrm{C}$. Parasagittal sections were obtained with a cryostat and collected on glass slides. Sections were subsequently immersed in $0.5 \% \mathrm{H}_{2} \mathrm{O}_{2}$ in PBS for $15 \mathrm{~min}$, washed in PBS + T and incubated overnight in the undiluted hybridoma supernatant from the $192 \mathrm{IgG}$ cell line (Chandler et al. 1984) at $4^{\circ} \mathrm{C}$. All the subsequent incubations were carried out at room temperature. After two washes in $\mathrm{PBS}+\mathrm{T}$, the tissue was incubated for $90 \mathrm{~min}$ in the undiluted hybridoma supernatant from the $\mathrm{McC10}$ cell line. After one wash in PBS $+\mathrm{T}$, the sections were incubated in $5 \mu \mathrm{g} / \mathrm{ml}$ HRP dissolved in PBS $+\mathrm{T}$, rinsed three times in PBS $+\mathrm{T}$ and reacted with DAB $(0.06 \%)$ and $\mathrm{H}_{2} \mathrm{O}_{2}(0.01 \%)$. The tissue was then dehydrated, clarified, mounted and then examined under bright field and interference-contrast optics.

For the detection of enkephalin immunoreactivity, a similar fixation procedure was applied except that the fixative used was simply $4 \%$ paraformaldehyde. Thirty-five $\mu \mathrm{m}$ sections of the spinal cord were generated using a sledge microtome and were incubated overnight with mouse anti-enkephalin monoclonal antibody coded $\mathrm{NOCl}$ (Cuello et al. 1984a). The reaction was developed, using $\mathrm{McC} 10$ as described above.

For electron microscopy, rat spinal cord tissue, prepared in accordance with Connaughton et al. (1986), was quickly frozen by immersion in liquid nitrogen and thawed in $0.1 \mathrm{M}$ phosphate buffer at $25^{\circ} \mathrm{C}$. Fifty $\mu \mathrm{m}$-thick sections were obtained with a Vibratome, treated for $30 \mathrm{~min}$ in $1 \%$ sodium borohydride in PBS and then rinsed several times in PBS (Kosaka et al. 1986). The sections were then incubated free-floating with mouse anti-enkephalin antibody, and the DAB reaction was carried out with double intensification as described by Adams (1981). Triton was not added to the tissue sections. After the DAB reaction, the tissue was rinsed twice with phosphate buffer, osmicated for $1 \mathrm{~h}$ in $1 \%$ osmium tetroxide in $0.1 M$ phosphate buffer at $4^{\circ} \mathrm{C}$, dehydrated and flatembedded in Epon between thick acetate foil and a plastic coverslip. After polymerization of the Epon, the sections were examined by light microscopy, and the selected fields were trimmed and reembedded for electron microscopic examination. The ultrathin sections were observed either uncontrasted or after double-contrast staining with uranyl and lead.

Fifty $\mu \mathrm{m}$ sections of human post-mortem samples from the frontal cortex of Alzheimer's patients were obtained using a sledgemicrotome, subsequently rinsed in PBS and incubated in $0.5 \%$ $\mathrm{H}_{2} \mathrm{O}_{2}$ in PBS for $15 \mathrm{~min}$ at room temperature. Immediately thereafter, the sections were rinsed twice in PBS and once in PBS $+\mathrm{T}$ and then incubated overnight with the $6.423 \mathrm{mAB}$ (Wischik et al. 1988 ) (diluted $1: 100$ ) in PBS $+\mathrm{T}$ at $4^{\circ} \mathrm{C}$. After two buffer rinses, the sections were then developed, using either $\mathrm{McC} 10$ as earlier 


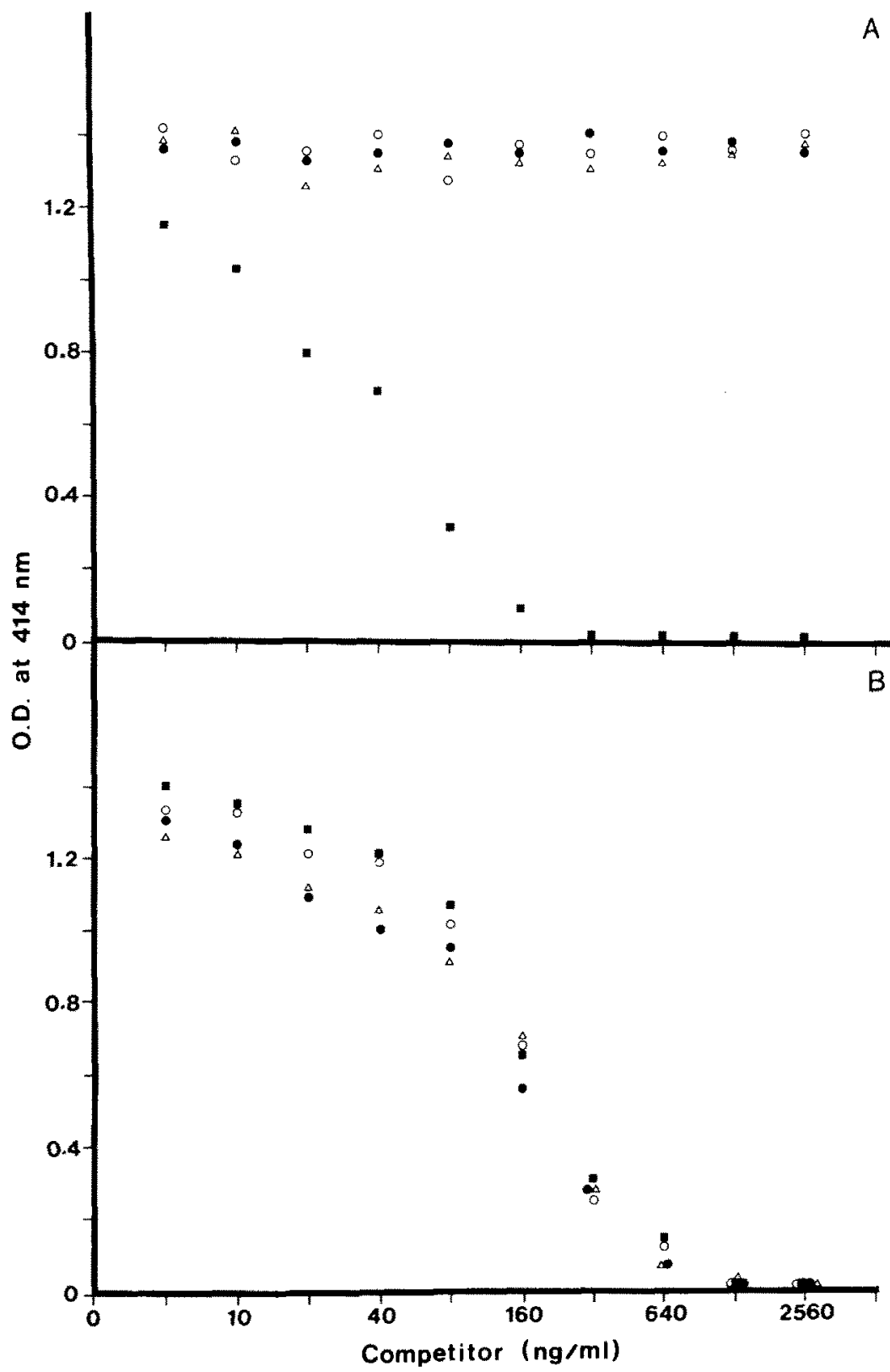

Fig. 1A, B. Competitive binding assays for McC10 expressed as optical density (O.D.) (ordinates) at $414 \mathrm{~nm}$ versus amount of competitor (abscissae). Displacement of binding of $\mathrm{McCl} 10$ to immobilized whole mouse $\operatorname{IgG}$ coated on microassay dishes was determined for mouse lambda (closed circles) and kappa light chains (closed squares) as well as $\operatorname{IgM}_{\mathrm{k}}$ (open circles) and $\operatorname{Ig} A_{1}$ (open triangles) in $A$; mouse $\operatorname{IgG}_{1 \mathrm{k}}$ (closed circles), $\operatorname{IgG}_{2 \mathrm{ak}}$ (open triangles), $\mathrm{IgG}_{2 \mathrm{bk}}$ (open circles) and $\operatorname{IgG}_{3 \mathrm{k}}$ (closed squares) in $B$. Values represent means obtained from quadruplicate assay wells described or the PAP procedure which employs rabbit antisera against mouse $\operatorname{Ig}(1: 50)$, followed by mouse anti-HRP $(1 ; 30)$ (Semenenko et al. 1985) supplemented with $5 \mu \mathrm{g} \mathrm{HRP} / \mathrm{ml}$.

\section{Results}

Five of the 6 rats which had been immunized with HRP were found to produce antiperoxidase antibodies as determined by PAP ICC for substance $P$ with the use of a rat anti-substance $\mathrm{P}$ monoclonal primary antibody (NC1-34) and rabbit anti-rat IgG antisera as the bridge antibody. The intensity of the immunostaining was very similar for sera from those animals immunized with 50 and $500 \mu \mathrm{g}$ of HRP and weakest for that from one rat immunized with a $5-\mu \mathrm{g}$ dose of peroxidase. One rat immunized with an intermediate dose was selected for cell fusion.
All of the six animals immunized with mouse $\operatorname{IgG}$ displayed some degree of antibody activity against whole mouse IgG as determined by the direct ELISA. One rat which received $50 \mu \mathrm{g}$ of the IgG per injection possessed the highest titre sera and was therefore selected for cell fusion.

Fusion efficiencies of the rat splenocytes with the mouse myeloma $\mathrm{Sp}_{2} / \mathrm{O} \cdot \mathrm{Ag}$ or the interspecies antiperoxidase hybridoma $\mathrm{RAP}_{2} \cdot \mathrm{Ag}$ were relatively high. Hybrid cell growth were detected in about $70 \%$ of the fusion wells of the former fusion and about $94 \%$ of the latter. The presence of antiperoxidase activity was evident in about $50 \%$ of the fusion wells tested. Wells containing hybrids with the highest antiperoxidase activity were cloned twice by limiting dilution, and the final clone was rendered resistant to 8-azaguanine. Aminopterin sensitivity was not accompanied by loss in specific anti- 


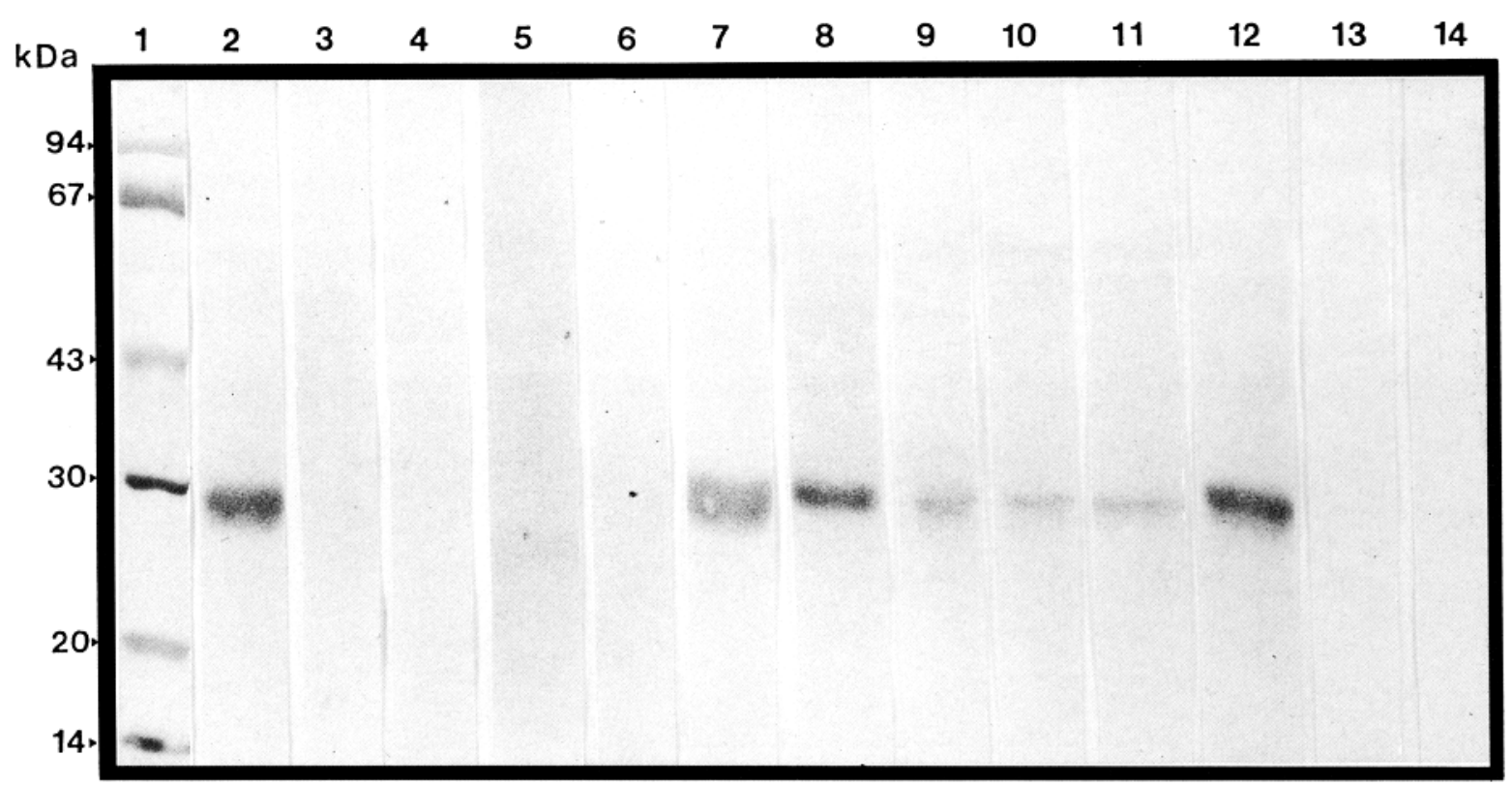

Fig. 2. Immunodetection of mouse kappa light chains on Western blots with the use of $\mathrm{McC} 10$. Whole mouse (lane 2), rat (lane 3) and rabbit (lane 4) $\mathrm{IgG}$, mouse $\operatorname{IgA} A_{1}$ (lane 5), $\operatorname{IgM}_{\mathrm{k}}$ (lanes 6 and 7 ), $\operatorname{IgG}_{\mathrm{kk}}$ (lane 8), $\operatorname{IgG}_{2 \mathrm{ak}}$ (lane 9), $\operatorname{IgG}_{2 \mathrm{bk}}$ (lane 10), $\operatorname{IgG}_{3 \mathrm{k}}$ (lane 11), mouse kappa (lane 12), rat kappa (lane 13) and mouse lambda (lane 14) light chains were separated electrophoretically

body production as revealed in the final cloning of $\mathrm{RAP}_{2} \cdot \mathrm{Ag}$.

Although fusion efficiency was somewhat higher with rat splenocytes from rats immunized with mouse $\mathrm{IgG}$ and the hybridoma $\mathrm{RAP}_{2} \cdot \mathrm{Ag}$, the presence of hybrid-hybridomas secreting the desired bi-specific antibodies was detected in only $30 \%$ of the fusion wells tested. Six fusion wells displaying the highest bi-specific antibody activity were retested by direct ELISA using the four mouse IgG subclasses as coating antigens. Two of the fusion wells contained hybrid-hybridomas which secreted bi-specific antibodies that recognized the $\operatorname{IgG}_{1}$ subclass only, one recognized $\operatorname{IgG}_{2 a}$ exclusively and three recognized both $\operatorname{IgG}_{2 a}$ and $\operatorname{IgG}_{2 b}$, while only two recognized all four subclasses. There appeared to be no wells containing clones which displayed exclusive recognition of either $\operatorname{IgG}_{2 b}$ or $\operatorname{IgG}_{3}$ alone. One fusion well, secreting bi-specific antibodies capable of binding all four IgG subclasses, was used for final cloning. One final clone, coded $\mathrm{McC10}$, was isolated and further characterized.

By radial immunodiffusion, the monoclonal antiperoxidase antibodies $\left(\mathrm{RAP}_{2}\right)$ were found to be of the $\operatorname{IgG}_{1}$ rat subclass, while the bi-specific antibodies (McC10) secreted by the hybrid-hybridoma were of the $\operatorname{IgG}_{1}$ and $\mathrm{IgG}_{2 \mathrm{a}}$ rat subclasses. Consequently, the $\operatorname{IgG}_{2 \mathrm{a}}$ portion of $\mathrm{McC} 10$ was undoubtedly inherited from its lymphocyte parent and contains the recognition sites for mouse Igs.

McC10 binding sites on mouse Ig were determined both in competitive binding assays and more directly on Western blots. In the competitive binding assays, $\mathrm{McC} 10$ was found to recognize all of the four mouse and then transferred to nitrocellulose membranes as described in the text. $\beta$-Mercaptoethanol was used as reducing agent for all samples except IgM (lane 7) where dithiothreitol was employed. Molecular weight standards were revealed with amido black (lane 1). Immunoreactivity was detected using $\mathrm{DAB}$ and $\mathrm{H}_{2} \mathrm{O}_{2}$ as substrates

IgG subclasses. Each of the subclass-specific IgGs were equally effective in displacing the binding of $\mathrm{McC} 10$ to immobilized whole mouse IgG coated on the microassay plate (Fig. 1B). Binding was competely displaced with $1.28 \mu \mathrm{g}$ of the IgG subclasses. In contrast, mouse IgA or IgM were not effective competitors (Fig. 1A). Since $\mathrm{McC1} 10$ appeared to cross-react only with the kappa light chains (Fig. 1 A), its lack of cross-reactivity with IgM was surprising as mouse IgM isolated from the TEPC tumour line contains kappa light chains.

This confusing finding from the competition assays was resolved on Western blots. Equimolar amounts of whole mouse, rat or rabbit $\operatorname{IgG}$, mouse $\operatorname{IgM}, \operatorname{Ig} A$, the four gamma subclasses of mouse $\operatorname{IgG}$ as well as lambda and kappa light chains of the mouse and rat kappa light chains, were electrophoretically separated on $10 \%$ polyacrylamide slab gels. The reactivity of $\mathrm{McC} 10$ revealed on immunoblots showed that McC10 exclusively recognized the mouse kappa light chains (Fig. 2). No crossreactivity with the three heavy chain classes, subclasses or lambda light chains was demonstrated. Furthermore, when $\operatorname{IgM}_{\mathbf{k}}$ was reduced with $\beta$-mercaptoethanol prior to separation and transfer, $\mathrm{McC} 10$ did not cross-react with this Ig (Fig. 2, lane 6). In contrast, when dithiothreitol was used as a reducing agent, a distinct band appeared at approximately $25 \mathrm{kDa}$, corresponding to the molecular weight of the light chain (Fig. 2, lane 7). Amido black staining of $\operatorname{IgM}$ after separation showed that reduction was incomplete with the use of $\beta$-mercaptoethanol.

The application of $\mathrm{McC} 10$ as a general developing reagent for the immunocytochemical detection of a variety of mouse primary antibodies of various classes and 

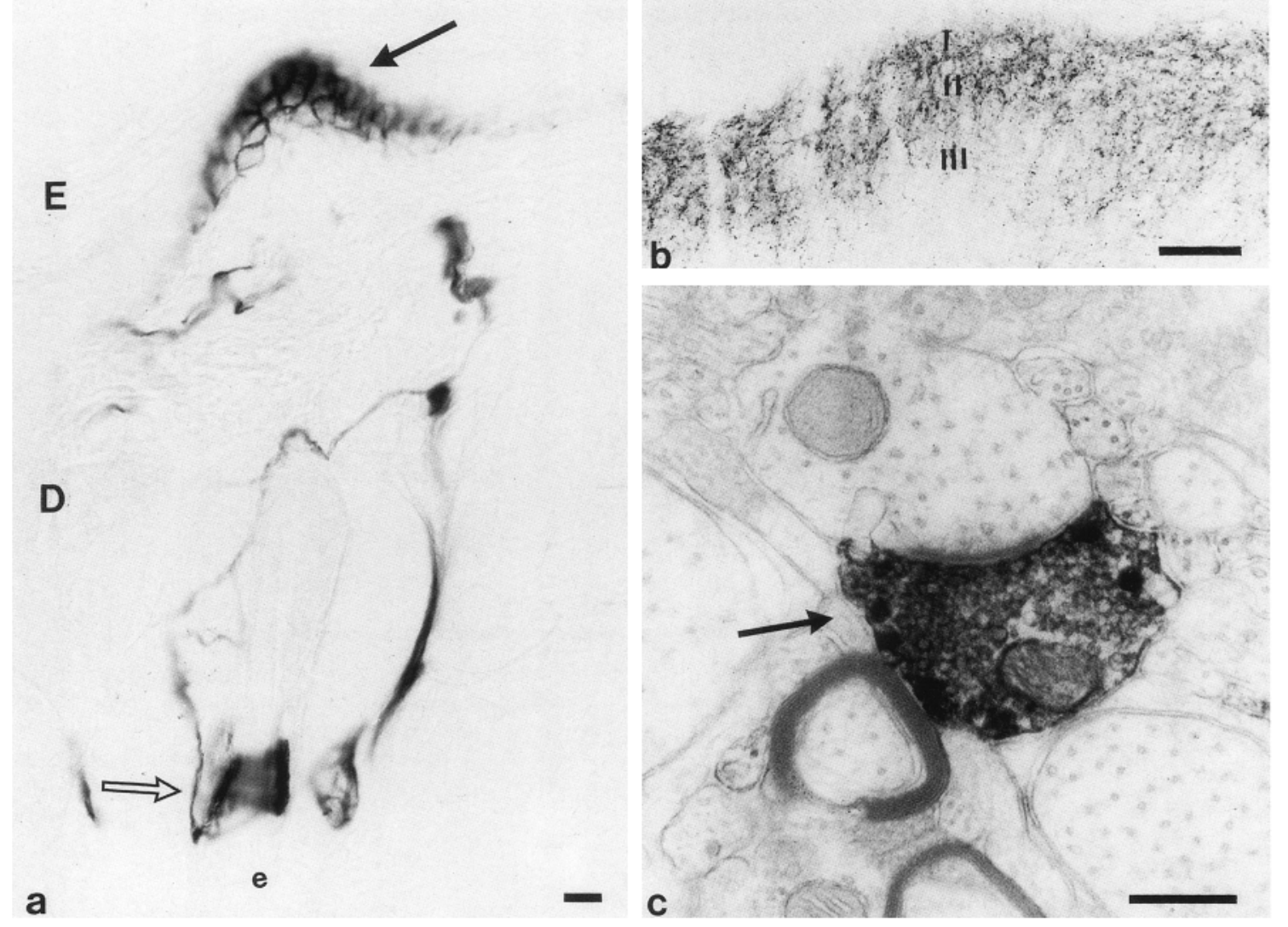

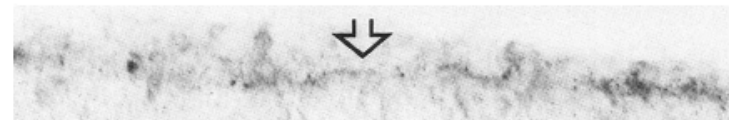
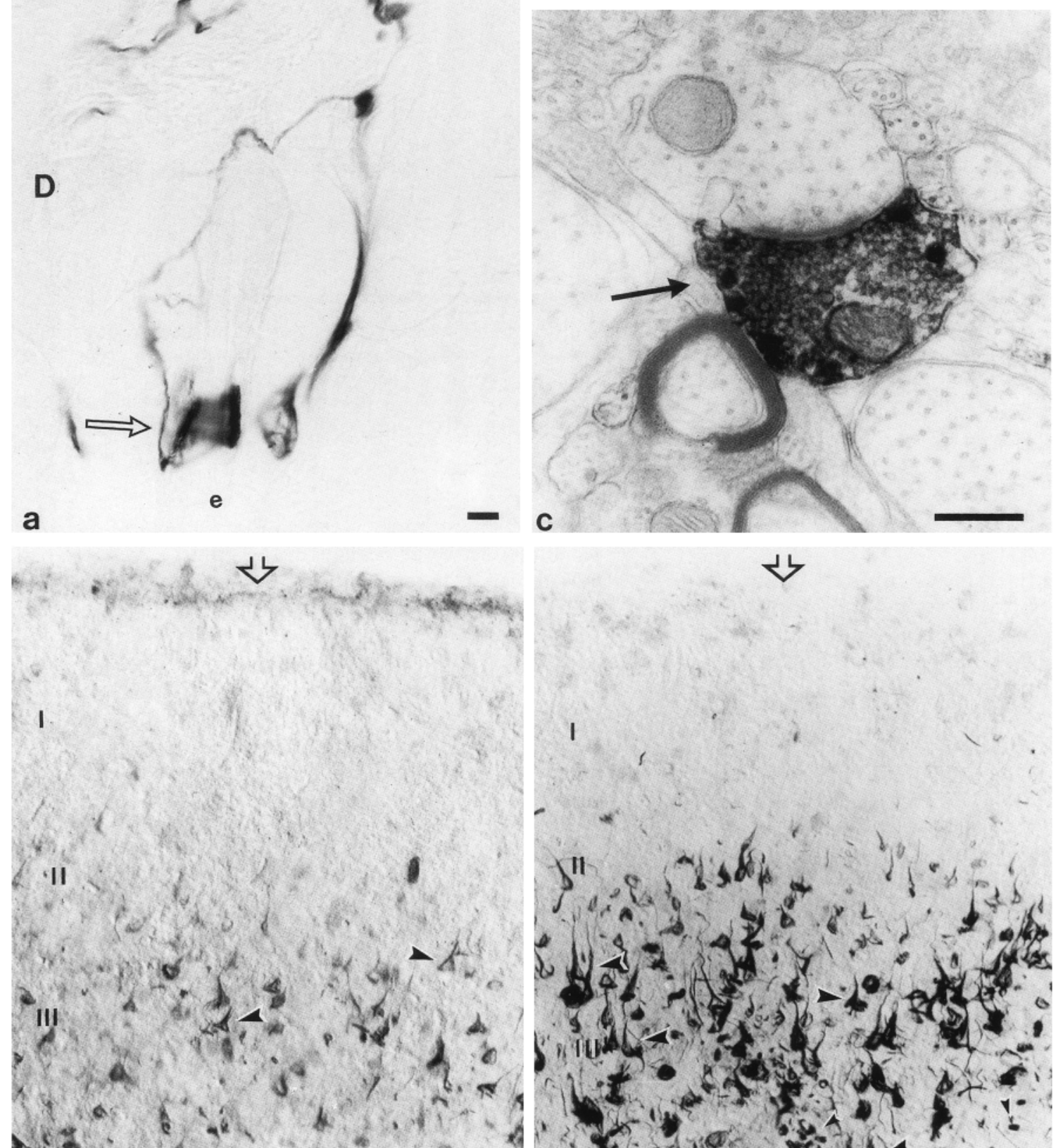

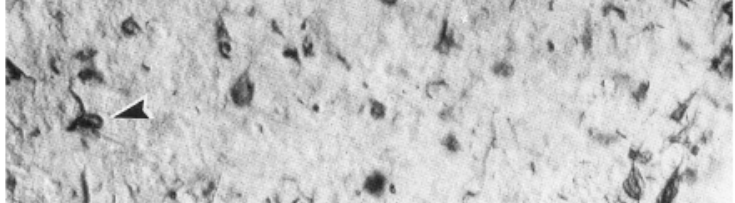

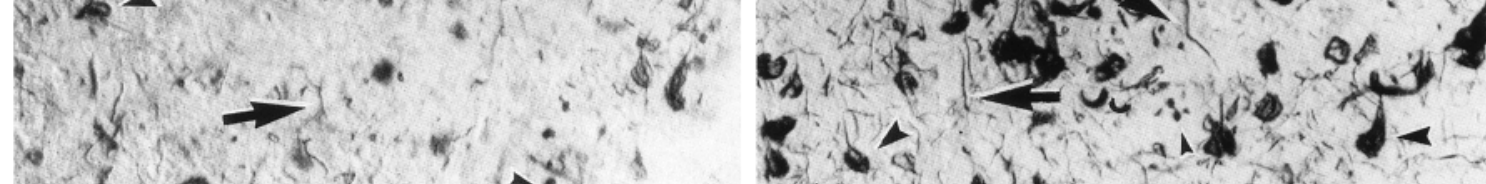

$y^{2}-1-2-5 \cdot 4-$ 
Table 1. Mouse Ig binding sites detected with $\mathrm{McC10}$

\begin{tabular}{|c|c|c|c|c|}
\hline Specificity & Reference & Code & $\begin{array}{l}\text { Ig Class } \\
\text { and } \\
\text { Subclass }\end{array}$ & Tissue \\
\hline $\begin{array}{l}\text { Tyrosine } \\
\text { hydroxylase }\end{array}$ & $\begin{array}{l}\text { Semenenko } \\
\text { et al. } \\
(1986)\end{array}$ & TOH-A1.1 & $\operatorname{IgG}_{1}$ & $\begin{array}{l}\text { Rat substan- } \\
\text { tia nigra }\end{array}$ \\
\hline $\begin{array}{l}\text { Leu-enkephalin } \\
\text { Met-enkephalin }\end{array}$ & $\begin{array}{l}\text { Cuello } \\
\text { et al. } \\
(1984 \mathrm{a})\end{array}$ & $\mathrm{NOC}_{1}$ & $\mathrm{IgG}_{3}$ & $\begin{array}{l}\text { Rat spinal } \\
\text { cord* }\end{array}$ \\
\hline NGF-receptor & $\begin{array}{l}\text { Chandler } \\
\text { et al. } \\
(1984)\end{array}$ & $192 \mathrm{IgG}$ & $\operatorname{IgG}_{1}$ & $\begin{array}{l}\text { Rat CNS, } \\
\text { skin* }\end{array}$ \\
\hline $\begin{array}{l}\text { Core of paired } \\
\text { helical filaments } \\
\text { (tau related } \\
\text { epitope) }\end{array}$ & $\begin{array}{l}\text { Wischik } \\
\text { et al. } \\
\text { (1988) }\end{array}$ & 6.423 & $\operatorname{IgG}_{2 \mathrm{~b}}$ & $\begin{array}{l}\text { Human post- } \\
\text { mortem } \\
\text { brain* (Alz- } \\
\text { heimer's } \\
\text { Disease) }\end{array}$ \\
\hline $\begin{array}{l}\text { Alzheimer's } \\
\text { protein A68 } \\
\text { (tau related } \\
\text { epitope) }\end{array}$ & $\begin{array}{l}\text { Wolozin } \\
\text { et al. } \\
(1986)\end{array}$ & AL50 & $\operatorname{IgM}$ & $\begin{array}{l}\text { Human post- } \\
\text { mortem brain }\end{array}$ \\
\hline
\end{tabular}

* Indicates results illustrated in Fig. 3

Fig. 3. a Photomicrograph of the skin of the rat lower lip, stained for the localization of nerve growth factor receptor-immunoreactive sites with the use of mouse IgG 192 followed by the bi-specific $\mathrm{McC} 10$ antibody. Note the complete absence of non-specific staining of collagen which is usually seen in samples rich in connective tissue. Arrowheads point to an area of epidermal staining, small arrow to nerves and the open arrow to a hair follicle receptor. $E$ - epidermis; $D$-dermis. Scale bar $=20 \mu \mathrm{m}$.

b-c Staining of the dorsal horn of rat spinal cord with the use of an anti-enkephalin monoclonal antibody and the bi-specific McC10. b Light microscopic photograph demonstrates enkephalin immunoreactivities in laminae I to III. Note absence of background staining, making the tissue landmarks difficult to recognize. Scale $b a r=20 \mu \mathrm{m}$. c Electron micrograph from lamina I, demonstrating a strongly anti-enkephalin immunoreactive axonal varicosity (arrow) with a few large granular and many agranular synaptic vesicles, presynaptic to a dendrite. Note the excellent preservation of the membranes and the virtual absence of non-specific staining. Scale bar $=0.5 \mu \mathrm{m}$.

d-e Frontal cortex from patient with Alzheimer's Disease, displaying immunoreactivity to the monoclonal antibody 6.423 directed against the pronase-resistant core of the paired helical filaments. The immunoreactivity was developed either with the PAP complex d or $\mathrm{McC} 10$ e. McC10 hybridoma supernatant immunoreactive neurofibrillary tangles (NFT, big arrowheads), enlarged neurites (small arrowheads) and thread-like elements (small arrows) appeared to be numerous and densely stained in cortical layers II and III. However, in adjacent section $\mathbf{d}$, fewer immunoreactive elements were visualized when the PAP procedure was applied and a non-specific reaction in the piamater (open arrow) was apparent. Interference contrast microscopy, $b a r=30 \mu \mathrm{m}$ subclasses is shown in Table 1 and Fig. 3. McC10 was used successfully in a number of different tissue preparations, revealing specific and distinct antigenic sites. Some of these findings are illustrated in Fig. 3 a where, in the skin of the rat lower lip, a tissue prone to high background staining in keratinous and collagen-rich structures, McC10 detected specific NGF-receptor-immunoreactive epidermis for the first time. These light microscopic observations revealed the finer details of the relationship that exists between NGF-receptor-bearing peripheral nerve fibers with blood vessels, epithelial patches and hair follicle structures. These observations are also being extensively reported elsewhere (A. Ribeiro-da-Silva, R.L. Kenigsberg and A.C. Cuello, submitted). $\mathrm{McC} 10$ was equally effective in revealing enkephalin-immunoreactive sites in nerve fiber networks of the superficial layers of the rat spinal cord (Fig. $3 \mathrm{~b}$ ). In addition, this bi-specific reagent was used in a shortened protocol for the localization of specific enkephalin immunoreactivity at the electron microscopic level which helped preserve ultrastructural detail (Fig. 3c).

Finally, the ultimate demonstration of the highly specific nature of $\mathrm{McC} 10$ is illustrated when difficult tissues like human brain pathological archive samples are employed. In this regard, specific paired helical filament immunoreactive sites could be revealed more readily with McC10 with little, if any, background staining (Fig. 3e) when compared to the PAP procedure (Fig. 3d). A full report of this observation will be published elsewhere (Mena et al., submitted).

\section{Discussion}

In this study, we report the development of a bi-specific monoclonal antibody that is capable of simultaneously recognizing mouse kappa light chains and the histochemical marker, HRP. This bi-specific antibody proves to be a truly universal developing reagent for the detection of mouse Igs. Although whole mouse IgG was used as the immunogen, we managed, by careful screening, to isolate a hybrid-hybridoma that produces bi-specific antibodies that recognize all four mouse gamma subclasses. In contrast to the human gamma subclasses which are remarkably similar, with $90-95 \%$ homology in the domain regions, the mouse gamma subclasses are only $60-70 \%$ homologous (Ellison and Hood 1982; Wang et al. 1980). Therefore, the likelihood that McC10 was binding to a conserved portion of the mouse gamma globulin chain, based on its cross-reactivity with all four gamma subclasses, and represented a heavy chain specific antibody, seemed unlikely. Upon further characterization of $\mathrm{McC} 10$, this proved not to be the case. The exclusive cross-reactivity $\mathrm{McC10}$ displays with the mouse kappa light chains has many advantages. For example, although the percentage of light chains represented by kappa or lambda classes varies among species, the kappa: lambda ratio is as high as 95:5 in the mouse (Nisonoff et al. 1975). In addition, as kappa or lambda light chains can pair equally well with any heavy chain class or subclass, one can assume that the majority of mouse 
Igs contain kappa light chains. Furthermore, as in the mouse, like the human, there is only one kappa constant region gene in the haploid genome and there exists only one kappa isotype form (Potter and Lieberman 1967). Finally, it has been shown that there exists only $37 \%$ homology between the kappa light chain constant regions from mouse, rat, human and rabbit (Novotny and Franck 1975), while heavy chain homology among these divergent species may be as high as 60-70\% (Jeske and Capra 1984). Consequently, it appears that we have, with the development of a kappa chain specific bi-specific monoclonal antibody, produced a highly selective developing reagent that should theoretically, recognize most of mouse Igs irrespective of heavy chain class or subclass. The potential merits of its high specificity renders this antibody very valuable in double-immunostaining procedures, where, for example, primary antibodies from other species are employed. Nevertheless, despite the theoretical assumptions made above, it appears that $\mathrm{McC10}$ does not cross-react with $\operatorname{IgM}_{\mathbf{k}}$ in a competitive binding assay. However, upon reduction of $\operatorname{IgM}$ with dithiothreitol, kappa light chain recognition was resumed. As circulating IgM normally exists as a pentamer of molecular weight $950 \mathrm{kDa}$, its structural configuration may hamper its interaction with $\mathrm{McC} 10$. However, the five monomeric units of the IgM molecule, which are arranged radially, have their Fc portions facing inwards and Fabs extending outwards (Eisen 1980). This arrangement should facilitate, rather than restrict, light chain cross-reactivity. Furthermore, when $\mathrm{McC} 10$ was used for the immunocytochemical detection of a mouse $\operatorname{IgM}$ primary antibody in fixed tissue preparations, these sites were revealed more readily (Table 1 ). Further studies might be required to explain this apparent discrepancy in the recognition of kappa light chains of the IgM molecule in different assay systems.

With respect to immunocytochemical detection of mouse primaries in particularly difficult tissue, a light chain specific antibody like $\mathrm{McC} 10$ would allow one to use $\mathrm{Fab}_{2}$ or Fab fragments as primary antibodies to further minimize background staining. Results from this study show that $\mathrm{McC} 10$ could be used for the detection of a variety of mouse primary antibodies. Even in difficult tissues like skin and human autopsy samples, specificity and low background staining were obtained despite the use of the whole Ig primary antibody. The enhanced specificity of a direct epitope-specific bi-specific developing reagent like $\mathrm{McC10}$ has been previously documented. Bi-specific anti-human $\mathrm{IgG}$ anti-HRP monoclonal antibodies were successfully used in clinical diagnoses of systemic lupus erythematosus and found to be more reliable for the accurate detection of circulating anti-nuclear antibodies in patient sera (Semenenko et al. 1988). In addition, anti anti-rabbit kappa light chain anti-HRP bi-specific monoclonal antibodies proved to be superior to conventional PAP when employed in tissue prone to display high background staining and were used successfully in a sensitive quantitative ELISA for the detection of a biologically active peptide (Kenigsberg et al. 1990). However, this bi-specific anti- body, unlike $\mathrm{McC} 10$, does exhibit some light chain allotype specificity (Kenigsberg et al. 1990).

In conclusion, bi-specific developing reagents like $\mathrm{McC} 10$ overcome the need for generating individual bispecifics for every antigen of interest and may ultimately serve to improve the quality, reproducibility and reliability of a number of immunobased procedures.

Acknowledgements. We wish to express our gratitude to Drs. A. Ribeiro-da Silva and R. Mena for providing us with unpublished immunocytochemical material, Ms. V. Wei and Mr. S. Cote for valued technical assistance and $\mathrm{Mr}$. A. Forster for the photographic work. This research was funded by grants from MRC (Canada) and Medicorp (Canada).

\section{References}

Adams JC (1981) Heavy metal intensification of DAB-based HRP reaction product. J Histochem Cytochem 29:775

Chandler CE, Parsons LM, Hosang M, Shooter EM (1984) A monoclonal antibody modulates the interaction of nerve growth factor with PC 12 cells. J Biol Chem 259:6882-6889

Connaughton M, Priestley JV, Sofroniew MV, Eckenstein F, Cuello AC (1986) Inputs to motoneurones in the hypoglossal nucleus of the rat: light and electron microscopic immunocytochemistry for choline acetyltransferase, substance $P$ and enkephalins using monoclonal antibodies. Neuroscience 17:205-224

Cuello AC, Milstein C (1981) Use of internally labelled monoclonal antibodies. In: Bizollon CA (ed) Physiological peptides and new trends in radioimmunology. Elsevier, Amsterdam, pp 293305

Cuello AC, Galfre G, Milstein C (1979) Detection of substance $\mathrm{P}$ in the central nervous system by a monoclonal antibody. Proc Natl Acad Sci USA 76:3532-3536

Cuello AC, Priestley JV, Milstein C (1982) Immunocytochemistry with internally labelled monoclonal antibodies. Proc Natl Acad Sci USA 79:665-669

Cuello AC, Milstein C, Couture R, Wright B, Priestley JV, Jarvis $\mathrm{J}$ (1984a) Characterisation and immunocytochemical applications of monoclonal antibodies against enkephalins. J Histochem Cytochem 32:947-957

Cuello AC, Milstein C, Wright B, Bramwell S, Priestley JV, Jarvis $J$ (1984b) Development and application of monoclonal rat peroxidase antiperoxidase (PAP) immunocytochemical reagent. Histochemistry $80: 257-261$

Eisen HN (1980) Immunology. Harper \& Row, Hagerstown, Maryland, USA

Ellison J, Hood L (1982) Linkage and sequence homology of two immunoglobulin gamma heavy chain constant region genes. Proc Natl Acad Sci USA 79:1984-1988

Jeske DJ, Capra JD (1984) Immunoglobulins: structure and function. In: Paul WE (ed) Fundamental immunology. Raven Press, New York, pp 131-165

Kenigsberg RL, Semenenko FM, Cuello AC (1990) Development of a bi-specific monoclonal antibody for simultaneous detection of rabbit IgG and horseradish peroxidase: use as a general reagent in immunocytochemistry and enzyme-linked immunosorbent assay. J Histochem Cytochem 38:191-198

Kohler G, Milstein C (1975) Continuous cultures of fused cells secreting antibody of pre-defined specificity. Nature 256:495497

Kohler G, Howe SC, Milstein C (1976) Fusion between immunoglobulin secreting and non secreting myeloma cell lines. Eur J Immunol 6:292-295

Kosaka T, Nagatsu I, Wu J-Y, Hama K (1986) Use of high concentrations of glutaraldehyde for immunocytochemistry of trans- 
mitter-synthesizing enzymes in the central nervous system. Neuroscience 18:975-990

MacMillan FM, Sofroniew MV, Sidebottom E, Cuello AC (1984) Immunocytochemistry with monoclonal anti-immunoglobulin as a developing reagent: application to immunoperoxidase staining and radioimmunocytochemistry. J Histochem Cytochem 32:76-82

Mason DY, Cordell JL, Abdulaziz Z, Naiem M, Bordenave G (1982) Preparation of peroxidase antiperoxidase (PAP) complexes for immunohistological labeling of monoclonal antibodies. J Histochem Cytochem 30:114-122

Mena R, Wischik CM, Novak M, Milstein C, Cuello AC (1990) A progressive deposition of paired helical filaments (PHF) in the brain characterizes the evolution of dementia in Alzheimer's Disease. An immunocytochemical study with a monoclonal antibody against the PHF core. (submitted)

Milstein C, Cuello AC (1983) Hybrid hybridomas and their use in immunohistochemistry. Nature 304:537-540

Milstein C, Cuello AC (1984) Hybrid hybridomas and the production of bi-specific monoclonal antibodies. Immunol Today 5:299-304

Munoz C, Nieto A, Gaya A, Martinez J, Vives J (1986) New experimental criteria for optimization of solid-phase antigen concentration and stability in ELISA. J Immunol Methods 94:137-144

Nisonoff A, Hopper JE, Spring SB (1975) The antibody molecule. Academic Press, New York

Norwood TH, Zeigler CJ, Martin GM (1976) Dimethyl sulfoxide enhances polyethylene glycol-mediated somatic cell fusion. Somat Cell Mol Genet 2:263-270

Novotny J, Franck F (1975) Different degrees of interspecies homology in immunoglobulin lamda chain constant domain correlated with three-dimensional structure. Nature 258:641-643

Potter M, Lieberman R (1967) Genetics of immunoglobulins in the mouse. Adv Immunol 7:91-145

Ribeiro-da-Silva A, Kenigsberg RL, Cuello AC (1990) Light and electron microscopic distribution of nerve growth factor receptor-like immunoreactivity in the skin of the rat lower lip. (submitted)
Semenenko FM, Bramwell S, Sidebottom E, Cuello AC (1985) Development of a mouse antiperoxidase secreting hybridoma for use in the production of a mouse PAP complex for immunocytochemistry and as a parent cell line in the development of hybrid-hybridomas. Histochemistry $83: 405-408$

Semenenko FM, Cuello AC, Goldstein M, Lee KY, Sidebottom E (1986) A monoclonal antibody against tyrosine hydroxylase: applications in light and electron microscopy. J Histochem Cytochem 34:817-821

Semenenko FM, Kenigsberg RL, Cuelio AC (1988) The production of a 'universal developer' for the immunological detection of human IgG and its application in immunodiagnostics. Histochemistry 90:315-321

Spitz M, Spitz L, Thorpe R, Eugui E (1984) Intrasplenic primary immunization for the production of monoclonal antibodies. J Immunol Methods 70:39-43

Sternberger LA, Hardy PH, Cuculis JJ, Meyer HG (1970) The unlabelled antibody enzyme method of immunohistochemistry: preparation, and properties of soluble antigen-antibody complex (horseradish peroxidase) and its use in identification of spirochetes. J Histochem Cytochem 18:315-333

Suresh MR, Cuello AC, Milstein C (1986) Advantages of bi-specific hybridomas in one-step immunocytochemistry and immunoassays. Proc Natl Acad Sci USA 83:7989-7993

Vaitukaitis J, Robbins JB, Nieschlog E, Ross GT (1971) A method for producing antisera with small doses of immunogen. J Clin Endocrinol Metab 33:988

Wang A-C, Tung E, Fundenberg HH (1980) The primary structure of a human $\operatorname{IgG}_{2}$ heavy chain: genetic evolutionary and functional implications. J Immunol 125:1048-1054

Wischik CM, Novak M, Thogersen HC, Edwards PC, Runswick MJ, Jakes R, Walker JE, Milstein C, Roth M, Klug A (1988) Isolation of a fragment of Tau derived from the core of the paired helical filament of Alzheimer disease. Proc Natl Acad Sci USA 85:4506-4510

Wolozin BL, Pruchnicki A, Dickson DW, Davies P (1986) A neuronal antigen in the brains of Alzheimer patients. Science 232:648-650 